\title{
CYCLICAL CHANGES IN UTERO-OVIDUCAL MOTILITY IN THE RABBIT
}

\author{
I. AREF* AND E. S. E. HAFEZ \\ Departments of Gynecology-Obstetrics and Physiology, Wayne State University, \\ School of Medicine, Detroit, Michigan, U.S.A.
}

(Received 16th Fune 1972)

The phasic activities of utero-oviducal musculature are co-ordinated to accomplish successful gamete transport. In untreated rabbits, the oviducal musculature shows dramatic daily changes in contractility (Salomy \& Harper, 1971). In oestrogen-treated rabbits, contractions are characterized by high frequency, small amplitude and irregular pattern (Mattos \& Coutinho, 1971). This oestrogen-dominated pattern is observed with either high or moderate doses of the steroid (Greenwald, 1963). During the luteal phase, the oviducal musculature becomes increasingly active (Boling, 1971) in response to increasing progestagen concentrations. Maximal contractility of the myometrium occurs during the preovulatory phase, and a 'myometrial block' (Csapo, 1970) is established during the luteal phase.

A chronological study of the characteristic motility patterns may provide a further understanding of their physiological implications. The purpose of this investigation was to study cyclical changes in the activity of musculature of the oviduct and uterus in the rabbit during the transport of gametes.

Balloon-ended, fluid-filled, polyethylene catheters were inserted in the lumen of the ampulla and the uterus of fourteen adult New Zealand rabbits in oestrus. Pressure fluctuations were transmitted and recorded using pressure transducers, a carrier preamplifier and a polygraph. Motility patterns were recorded during oestrus and for the first 5 days post coitum (p.c.). Does were mated to fertile bucks $48 \mathrm{hr}$ after the insertion of catheters.

During oestrus, the oviducal contractions were characterized by high frequency, low amplitude, and a slight change in tonus, as indicated by the instability of the resting pressure (Text-fig. 1A); in three rabbits, however, this pattern was not observed and the contractions were irregular and variable (Table 1). Following copulation, a progressive increase in activity was noted and, by $6 \mathrm{hr}$ p.c., the active oviducal motility was characterized by high frequency and amplitude of contractions and regularly repeated outbursts of increased tonus (Text-fig. 1B). The activity was reduced at $24 \mathrm{hr}$ p.c. (Text-fig. 1C) and, at $60 \mathrm{hr}$ p.c., an alternating rhythm was associated with rapid and slow sets of contractions (Text-fig. ID). Rapid sets of contractions were abolished $72 \mathrm{hr}$ p.c. (Text-fig. IE). The relatively infrequent contractions were predominant. A progressive slowing down in frequency and an increase in the

\footnotetext{
* Present address: Department of Obstetrics-Gynecology, Al Azhar University, School of Medicine, Darrasa, Cairo, Egypt.
} 
amplitude was observed daily (Text-fig. IF). In two rabbits, an active motility pattern was established $1 \mathrm{hr}$ p.c., but it changed suddenly, bypassing the gradual change typically recorded at 24 and $48 \mathrm{hr}$ p.c. (Table 1).

During oestrus, three different uterine motility patterns were frequently observed: rhythmic, arrhythmic, and combined (Text-fig. 1A). Rhythmic contractions were characterized by large amplitude, short duration and low frequency. Arrhythmic contractions were characterized by small amplitude, prolonged duration and high frequency. The third type was a combination of

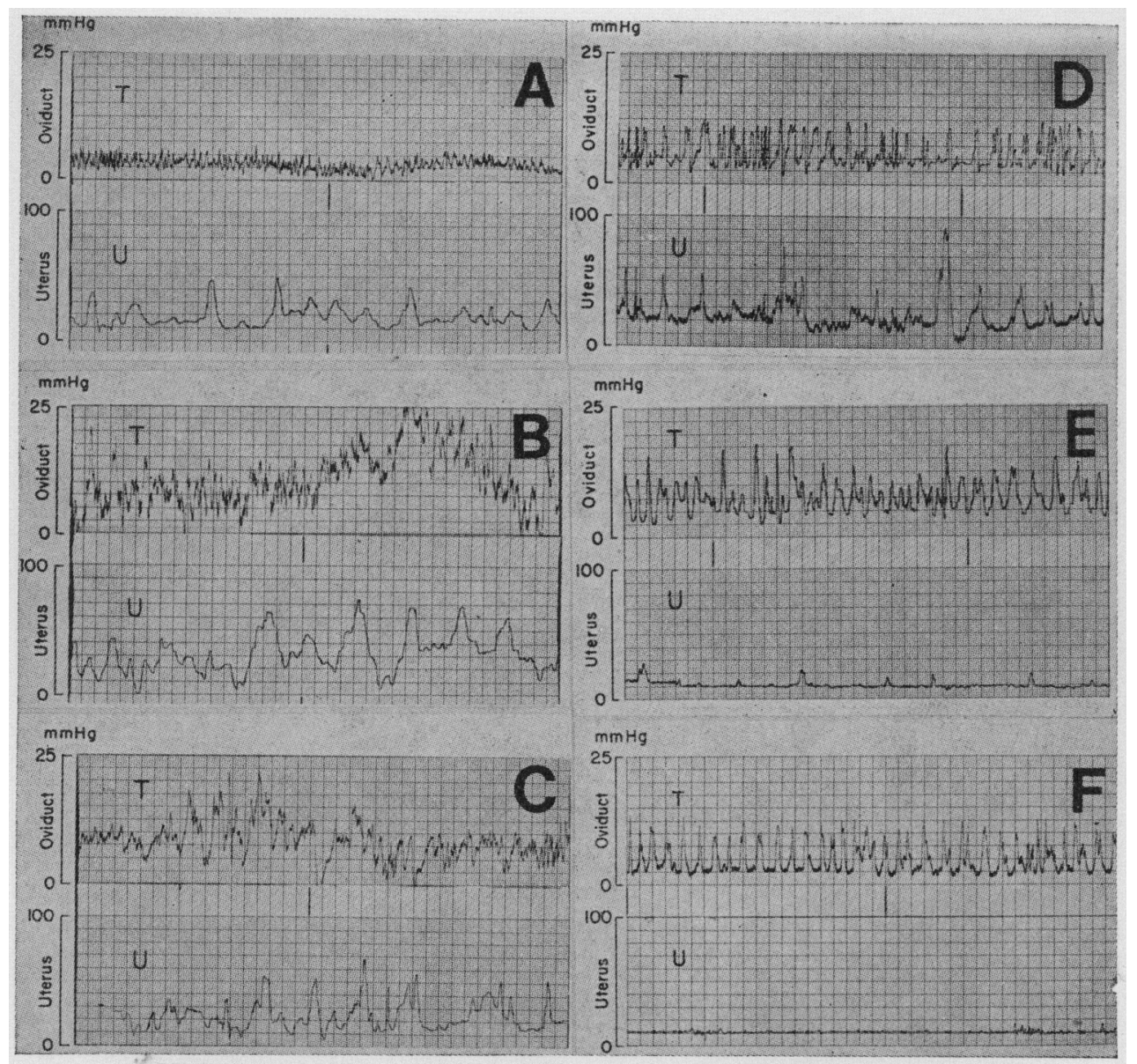

TexT-Fic. 1. Cyclical variations in utero-oviducal motility in rabbits. A: oestrus; B: 1 to 6 hr p.c.; C: $24 \mathrm{hr}$ p.c.; D: $60 \mathrm{hr}$ p.c.; E: $72 \mathrm{hr}$ p.c.; F: 96 hr. p.c. Each graph represented 25 min of simultaneous, continuous recording. Maximal activity of both uterine and oviducal musculature was exhibited 1 to $6 \mathrm{hr}$ p.c. At 72 and $96 \mathrm{hr}$ p.c., intensive oviducal activity was contrasted with blocked myometrial activity.

these two patterns. An initial rapid increase in uterine activity 1 to $6 \mathrm{hr}$ after copulation (Text-fig. 1B) was followed by a gradual, progressive decline in contractility (Text-figs $1 \mathrm{C}$ and D). At $72 \mathrm{hr}$ p.c. (Text-fig. 1E), uterine activity was blocked in six rabbits and depressed in five others (Table 2). At $96 \mathrm{hr}$ p.c. 
Table 1. Typical and atypical patterns of oviducal motility in the rabbit

\begin{tabular}{|c|c|c|c|c|}
\hline \multirow{2}{*}{$\begin{array}{l}\text { Hours } \\
\text { post } \\
\text { coitum }\end{array}$} & \multirow{2}{*}{$\begin{array}{l}\text { No. of } \\
\text { rabbits } \\
\text { tested }\end{array}$} & \multicolumn{2}{|c|}{ Typical oviducal motility } & \multirow{2}{*}{$\begin{array}{c}\text { No. of rabbits } \\
\text { showing atypical } \\
\text { motility }\end{array}$} \\
\hline & & Pattern & Resting pressure & \\
\hline Oestrus* & 10 & $\begin{array}{l}\text { Active, } \\
\text { high frequency and } \\
\text { low amplitude }\end{array}$ & Slightly variable & 3 \\
\hline 1 & 11 & $\begin{array}{l}\text { Very active, } \\
\text { high frequency and } \\
\text { high amplitude }\end{array}$ & $\begin{array}{l}\text { Markedly variable } \\
\text { with outburst of } \\
\text { increasing tonus }\end{array}$ & 3 \\
\hline 3 & 11 & $\begin{array}{l}\text { Very active, } \\
\text { high frequency and } \\
\text { high amplitude }\end{array}$ & $\begin{array}{l}\text { Markedly variable } \\
\text { with outburst of } \\
\text { increasing tonus }\end{array}$ & 1 \\
\hline 6 & 11 & $\begin{array}{l}\text { Very active, } \\
\text { high frequency and } \\
\text { high amplitude }\end{array}$ & $\begin{array}{l}\text { Markedly variable } \\
\text { with outburst of } \\
\text { increasing tonus }\end{array}$ & 0 \\
\hline 24 & 10 & $\begin{array}{l}\text { Active, low frequency, } \\
\text { higher amplitude and } \\
\text { prolonged duration }\end{array}$ & Variable & 2 \\
\hline 60 & 9 & $\begin{array}{l}\text { Alternating } \\
\text { successive rapid and slow } \\
\text { sets of intense } \\
\text { contractions }\end{array}$ & Stable & 2 \\
\hline 72 & 8 & $\begin{array}{l}\text { Slow } \\
\text { intense sustained } \\
\text { contractions }\end{array}$ & Stable & 0 \\
\hline 96 & 3 & $\begin{array}{l}\text { Progressive slowing down } \\
\text { associated with increase } \\
\text { in the contraction } \\
\text { amplitude and duration }\end{array}$ & Stable & 0 \\
\hline 120 & 3 & $\begin{array}{l}\text { Progressive slowing down } \\
\text { associated with increase } \\
\text { in the contraction } \\
\text { amplitude and duration }\end{array}$ & Stable & 0 \\
\hline
\end{tabular}

* An oestrous pattern of motility was maintained for 2 successive days before copulation was allowed.

Table 2. Rabbit uterine activity post coitum

\begin{tabular}{c|c|c|c|c}
\hline \multirow{3}{*}{ Hours post coitum } & \multicolumn{3}{|c|}{ No. of rabbits in which uterine activity: } \\
\cline { 2 - 5 } & Increased & $\begin{array}{c}\text { Remained } \\
\text { unchanged }\end{array}$ & Decreased & $\begin{array}{c}\text { Was } \\
\text { blocked }\end{array}$ \\
\hline 1 & 10 & 3 & 1 & 0 \\
24 & 0 & 12 & 2 & 0 \\
60 & 0 & 3 & 7 & 4 \\
72 & 0 & 2 & 5 & 6 \\
96 & 0 & 0 & 2 & 11 \\
120 & 0 & 0 & 0 & 13 \\
\hline
\end{tabular}


(Text-fig. 1E), uterine activity was blocked in eleven rabbits and depressed in two others.

The p.c. changes have physiological significance in ova picked up by the fimbriae and ova retained at the ampullary-isthmic junction. On the other hand, the dramatic p.c. changes in the myometrial activity play a major rôle in sperm migration to the ampulla, transport of ova through the uterotubal junction, and spacing the implanting blastocyst along the uterine wall. In the rabbit, the pacemaker of oviducal muscular activity is located at a discrete area around the ampullary-isthmic junction (Talo \& Brundin, 1971), and its activity may be influenced by its adrenergic nerves densely located at the same area (Owman \& Sjoberg, 1966). Adrenergic $\alpha$-constricting receptors are activated by noradrenaline, while both $\alpha$ - and $\beta$-dilating receptors are activated by adrenaline (Seitchik, Goldberg, Goldsmith \& Pauerstein, 1968; Coutinho, 1970). Ovarian steroids modify the activity of these receptors since they increase the noradrenaline content of the isthmus (Bodkhe \& Harper, 1972a, b). In goats, pronounced electrical activity and groups of positive pulses occur during oestrus, and sets of negative pulses dominate during dioestrus (Larks, Larks, Hoffer \& Charlson, 1972). In women, local release of adrenergic amines may evoke outbursts of increased oviducal muscular activity (Coutinho \& Maia, 1969).

This investigation was supported by The Ford Foundation grant No. 710-0287 and by the National Institute of Child Health and Human Development grant No. HD 06234.

\section{REFERENCES}

BODKHe, R. R. \& HARPER, M. J. K. (1972a) Mechanism of egg transport: changes in the genital tract of normal and hormone treated rabbits. In: The Regulation of Mammalian Reproduction. Eds. S. J. Segal, R. Grozier and P. Corfman. C. C. Thomas, Springfield, Illinois (in press).

Bodkhe, R. R. \& HARPer, M. J. K. (1972b) Changes in the amount of adrenergic neurotransmitter in the genital tract of untreated rabbits and rabbits given reserpine or iproniazid during the time of egg transport. Biol. Reprod. 6, 288.

Boling, J. L. (1971) The endocrinology of the oviduct. In: Pathways to Conception, p. 3. Ed. A. I. Sherman. G. C. Thomas, Springfield, Illinois.

Coutinнo, E. M. (1970) Tubal and uterine motility. In: Control of Human Fertility, Nobel Symposium 15, p. 97. Eds E. Diczfalusy and U. Borell. Wiley, New York.

Coutinho, E. M. \& Maia, H. (1969) Asynchronism between tubal and uterine activity in women. $\mathcal{J}$. Reprod. Fert. 19, 591 .

Csapo, A. (1970) The diagnostic significance of the intrauterine pressure. I and II. Obstetel gynec. Surv. 25, 403.

Greenwai.D, G. S. (1963) In vivo recording of intraluminal pressure changes in the rabbit oviduct. Fert.Steril. 14, 666.

Larks, S. D., Larks, G. G., Hoffer, R. E. \& Charlson, E. J. (1972) Electrical activity of oviducts in vivo. Nature, Lond. 234, 556.

Mattos, C. E. R. \& Coutinho, E. M. (1971) Effects of the ovarian hormones on tubal motility of the rabbit. Endocrinology, 98, 912.

Owman, C. \& SJoberg, N. (1966) Adrenergic nerves in the female genital tract of the rabbit, with remarks on cholinesterase-containing structures. Z. Zellforsch. mikrosk. Anat. 74, 182.

Salomy, M. \& Harper, M. J. K. (1971) Gyclical changes of oviduct motility in rabbits. Biol. Reprod. 4, 185.

Seitchik, J., Goldberg E., Goldsmith, J. P. \& Pauerstein, C. J. (1968) Pharmacodynamic studies of the human fallopian tube in vitro. Am. J. Obstet. Gynec. 102, 727.

TAlo, A. \& Brundin, J. (1971) Muscular activity in the rabbit oviduct; a combination of electric and mechanic recordings. Biol. Reprod. 5, 67. 